\title{
Front Matter: Volume 9766
}

, "Front Matter: Volume 9766," Proc. SPIE 9766, Vertical-Cavity SurfaceEmitting Lasers XX, 976601 (22 June 2016); doi: 10.1117/12.2239802

SPIE. Event: SPIE OPTO, 2016, San Francisco, California, United States 


\section{PROCEEDINGS OF SPIE}

\section{Vertical-Cavity Surface-Emitting Lasers XX}

Kent D. Choquette

James K. Guenter

Editors

17-18 February 2016

San Francisco, California, United States

Sponsored and Published by

SPIE

Volume 9766 
The papers in this volume were part of the technical conference cited on the cover and title page. Papers were selected and subject to review by the editors and conference program committee. Some conference presentations may not be available for publication. Additional papers and presentation recordings may be available online in the SPIE Digital Library at SPIEDigitallibrary.org.

The papers reflect the work and thoughts of the authors and are published herein as submitted. The publisher is not responsible for the validity of the information or for any outcomes resulting from reliance thereon.

Please use the following format to cite material from these proceedings:

Author(s), "Title of Paper," in Vertical-Cavity Surface-Emitting Lasers XX, edited by Kent D. Choquette, James K. Guenter, Proceedings of SPIE Vol. 9766 (SPIE, Bellingham, WA, 2016) Six-digit Article CID Number.

ISSN: 0277-786X

ISSN: 1996-756X (electronic)

ISBN: 9781510600010

Published by

SPIE

P.O. Box 10, Bellingham, Washington 98227-0010 USA

Telephone +1 3606763290 (Pacific Time) · Fax +1 3606471445

SPIE.org

Copyright (c) 2016, Society of Photo-Optical Instrumentation Engineers.

Copying of material in this book for internal or personal use, or for the internal or personal use of specific clients, beyond the fair use provisions granted by the U.S. Copyright Law is authorized by SPIE subject to payment of copying fees. The Transactional Reporting Service base fee for this volume is $\$ 18.00$ per article (or portion thereof), which should be paid directly to the Copyright Clearance Center (CCC), 222 Rosewood Drive, Danvers, MA 01923. Payment may also be made electronically through CCC Online at copyright.com. Other copying for republication, resale, advertising or promotion, or any form of systematic or multiple reproduction of any material in this book is prohibited except with permission in writing from the publisher. The CCC fee code is 0277-786X/16/\$18.00.

Printed in the United States of America.

Publication of record for individual papers is online in the SPIE Digital Library.

\section{SPIE. DIGITAL}

Paper Numbering: Proceedings of SPIE follow an e-First publication model. A unique citation identifier (CID) number is assigned to each article at the time of publication. Utilization of CIDs allows articles to be fully citable as soon as they are published online, and connects the same identifier to all online and print versions of the publication. SPIE uses a six-digit CID article numbering system structured as follows:

- The first four digits correspond to the SPIE volume number.

- The last two digits indicate publication order within the volume using a Base 36 numbering system employing both numerals and letters. These two-number sets start with 00, 01, 02, 03, 04, $05,06,07,08,09,0 A, 0 B \ldots$ OZ, followed by 10-1Z, 20-2Z, etc. The CID Number appears on each page of the manuscript. 


\title{
Contents
}

\author{
$\checkmark \quad$ Authors \\ vii Conference Committee
}

NOVEL VCSEL STRUCTURES

976605 780nm-range VCSEL array for laser printer system and other applications at Ricoh (Invited Paper) [9766-4]

976606 VCSELs for interferometric readout of MEMS sensors (Invited Paper) [9766-5]

976607 Dynamic properties of silicon-integrated short-wavelength hybrid-cavity VCSEL [9766-6]

976608 Direct visualization of the in-plane leakage of high-order transverse modes in verticalcavity surface-emitting lasers mediated by oxide-aperture engineering [9766-7]

976609 Passive cavity surface-emitting lasers: option of temperature-insensitive lasing wavelength for uncooled dense wavelength division multiplexing systems [9766-8]

EMERGING VCSEL APPLICATIONS

9766 OA VCSEL-based sensors for distance and velocity (Invited Paper) [9766-9]

9766 OB Progress in high-power high-speed VCSEL arrays (Invited Paper) [9766-10]

9766 0C Developments of VCSELs for printers and optical communications at Fuji Xerox (Invited Paper) [9766-11]

9766 OD High-efficiency VCSEL arrays for illumination and sensing in consumer applications [9766-12]

VCSEL RELIABILITY AND MANUFACTURE

9766 OF Failure mode analysis of degraded InGaAs-AIGaAs strained quantum well multi-mode vertical-cavity surface-emitting lasers [9766-14]

9766 OG VCSEL-based flexible opto-fluidic fluorescence sensors [9766-15]

$9766 \mathrm{OH} \quad$ Controlling the parameters of wet lateral oxidation for VCSEL fabrication [9766-16] 
9766 Ol Beam quality study for single-mode oxide-confined and photonic crystal VCSELs (Invited Paper) [9766-17]

9766 0J Low-dispersion ultra-high-bandwidth vertical-cavity surface-emitting laser arrays [9766-18]

9766 OK Close to $100 \mathrm{Gbps}$ discrete multitone transmission over $100 \mathrm{~m}$ of multimode fiber using a single transverse mode $850 \mathrm{~nm}$ VCSEL [9766-19]

$9766 \mathrm{OL}$ Influence of birefringence splitting on ultrafast polarization oscillations in VCSELs [9766-20]

$97660 \mathrm{M}$ Monolithic subwavelength high refractive-index-contrast grating VCSELs [9766-21] 


\section{Authors}

Numbers in the index correspond to the last two digits of the six-digit citation identifier (CID) article numbering system used in Proceedings of SPIE. The first four digits reflect the volume number. Base 36 numbering is employed for the last two digits and indicates the order of articles within the volume. Numbers start with 00, 01, 02, 03, 04, 05, 06, 07, 08, 09, 0A, OB...0Z, followed by 10-1Z, 20-2Z, etc.

Abell, David J., OB

Agustin, Mikel, OK

Baets, Roel, 07

Baker, Michael S., 06

Blane, Janice T., Ol

Blokhin, A. A., 09

Blokhin, S. A., 09

Brodie, Miles, OF

Burger, S., 08

Bushmaker, Adam, OF

Carpaii, Mark, OA

Carson, Richard F., OB

Chacko, David B., Ol

Chao, Lu, OK

Chen, Tong, OD

Choquette, Kent D., 09, 0J

Czyszanowski, Tomasz, OM

Dacha, Preethi, OB

Dems, Maciej, OM

Dencker, Jonathan B., Ol

Eddie, Iain, OK

Feng, Zhiyong, OK

Foran, Brendan, OF

Fryslie, Stewart T. M., 0J

Gai, Boju, OG

Gębski, Marcin, OM

Geib, Kent M., 06

Gerhardt, Nils C., OL

Gerlach, Philipp, OA

Ghosh, Chuni, OD

Gordeev, N. Yu., 09

Gronenborn, Stephan, OA

Gu, Xiaodong, OC

Gudde, Ralph, OA

Guo, Baiming, OD

Gustavsson, Johan S., 07

Haglund, Emanuel P., 07

Harasaka, Kazuhiro, 05

Hellmig, Jochen, OA

Hofmann, Martin R., OL

Huang, Michael, OF

Ingold, Kirk A., Ol

Itoh, Akihiro, 05

Jikutani, Naoto, 05

Kang, Dongseok, OG

Keeler, Gordon A., 06

Kolb, Johanna, OA

Kondo, Takashi, OC

Kor, Alex, $\mathrm{OH}$
Koyama, Fumio, 0C

Kropp, Joerg,R., 08, OK

Kumari, Sulakshna, 07

Larsson, Anders, 07

Ledentsov, Nikolay N., 08, 09, OK

Ledentsov, Nikolay, Jr., 08, OK

Li, Daizong, OD

Lindemann, Markus, OL

Lingley, Zachary, OF

Lott, James A., OB, OM

LUo, Jun, OK

Luo, Yazhi, OK

Ma, Yanan, OK

Maleev, N. A., 09

Maximov, M. V., 09

Maynard, John G., OB

Meredith, W., 09

Michalzik, Rainer, OL

Miglo, Alexander, OD

Moench, Holger, OA

Moss, Steven C., OF

Murakami, Akemi, OC

Nadtochy, A. M., 09

Nakayama, Hideo, $0 \mathrm{C}$

North, William K., Ol

Okandan, Murat, 06

Otis, Kirk J., OB

Otoma, Hiromi, OC

Payusov, A. S., 09

Peake, Gregory M., 06

Presser, Nathan, OF

Pusch, Tobias, OL

Qiv, Shaofeng, OK

Raftery, James J., Jr., Ol

Reed, David, $\mathrm{OH}$

Riaziat, Majid, $\mathrm{OH}$

Roelkens, Gunther, 07

Sakurai, Jun, OC

Sasaki, Toshihide, 05

Sato, Shunichi, 05

Schmidt, F., 08

Serkland, Darwin K., 06

Seurin, Jean-Francois, OD

Shaw, Michael J., 06

Shchukin, Vitaly A., 08, 09, OK

Sin, Yongkun, OF

Slight, T., 09

Souhan, Brian, 0 I

Takeda, Kazutaka, 0C 
Theiss, Jesse, OF

Ustinov, V. M., 09

van der Lee, Alexander, OA

Warren, Mial E., OB

Westbergh, Petter, 07

Wilcox, Thomas, OB

Wu, Bo, OK

Xu, Guoyang, OD

Yoon, Jongseung, OG

Zadiranov, Yu. M., 09

Zeidler, Peter R., Ol

Zhong, Kangping, OK

Zhou, Delai, OD

Zhou, Xian, OK

Proc. of SPIE Vol. $9766976601-6$

Downloaded From: https://www.spiedigitallibrary.org/conference-proceedings-of-spie on 26 Apr 2023 Terms of Use: https://www.spiedigitallibrary.org/terms-of-use 


\section{Conference Committee}

Symposium Chairs

Jean-Emmanuel Broquin, IMEP-LAHC (France)

Shibin Jiang, AdValue Photonics, Inc. (United States)

\section{Symposium Co-chairs}

David L. Andrews, University of East Anglia (United Kingdom)

Alexei L. Glebov, OptiGrate Corporation (United States)

Program Track Chair

Klaus P. Streubel, OSRAM AG (Germany)

Conference Chairs

Kent D. Choquette, University of Illinois at Urbana-Champaign (United States)

James K. Guenter, Finisar Corporation (United States)

Conference Program Committee

Nicolae Chitica, TE Connectivity Ltd. (Sweden)

Aaron James Danner, National University of Singapore (Singapore)

Kent M. Geib, Sandia National Laboratories (United States)

Martin Grabherr, Philips Technologie GmbH U-L-M Photonics

(Germany)

Anders Larsson, Chalmers University of Technology (Sweden)

Chun Lei, EMCORE Corporation (United States)

James A. Lott, Technische University Berlin (Germany)

M. V. Ramana Murty, Avago Technologies Ltd. (United States)

Krassimir Panajotov, Vrije Universiteit Brussel (Belgium)

Jean-Francois Seurin, Princeton Optronics, Inc. (United States)

Noriyuki Yokouchi, Furukawa Electric Company, Ltd. (Japan)

Jongseung Yoon, The University of Southern California (United States)

Mial E. Warren, TriLumina Corporation (United States)

Session Chairs

1 Celebration of 20 Years of VCSELs at Photonics West

Chun Lei, EMCORE Corporation (United States) 
2 Novel VCSEL Structures

Jack Jewell, TJ Optics Inc. (United States)

3 Emerging VCSEL Applications

Darwin K. Serkland, Sandia National Laboratories (United States)

$4 \quad$ VCSEL Reliability and Manufacture

Kent D. Choquette, University of Illinois at Urbana-Champaign (United States)

5 VCSEL Modulation and Characteristics

James Guenter, Finisar Corporation (United States) 